\title{
AN EXPRESSIVE THEORY OF CONTRACT: FROM FEMINIST DILEMMAS TO A RECONCEPTUALIZATION OF RATIONAI CHOICE IN CONTRACT LAW
}

\author{
GILLIAN K. HADFIELD $\dagger$
}

\section{INTRODUCTION}

How do people choose? This question figures prominently in essentially any field that places human behavior within its province. Choice is a way of describing human action; we can always look at how one has behaved and indicate how this behavior has affected a choice, even if we do not think that choicemaking was part of an individual's self-understanding of her behavior. Distinctive disciplines have distinctive ways of understanding choice: Sociologists might see an individual's choices as determined by that person's socioeconomic identity, role models, or institutional structures; psychologists, a set of perhaps unconscious preoccupations rooted in early childhood experiences or current struggles with self-image; sociobiologists, genetic predispositions and the demands of the struggle for survival. From these differing perspectives flow different predictions, descriptions, and explanations for the behavior we observe.

As a discipline, law is interested in how people choose in order to judge behavior; to decide, from a normative perspective, whether and how behavior should be constrained or sanctioned. The particular predictive, descriptive, or explanatory theories of behavior that the law draws on thus can play a tremendously important role in the normative design of legal rules and institutions. Behavior understood to be driven by biological, psychological, or sociological factors beyond individual control, for example, may be treated in the law differently than behavior that is understood to be the product of free

† Associate Professor, Faculty of Law, University of Toronto. I am very grateful to a number of colleagues for comments on earlier versions of this Article, including Alan Brudner, Bruce Chapman, Norman Siebrasse, and Hamish Stewart, and the participants in seminars at Columbia Law School, Cornell School of Law, McGill Law School, the University of Pennsylvania Law School, the University of Melbourne, and the Canadian Law and Economics Association Annual Meeting. I have also benefited from conversations about this topic with Stephen Grant, Mayo Moran, Michael Trebilcock, and Catherine Valcke. 
and deliberate choice. Both principled inquiries into moral accountability and pragmatic inquiries into the efficacy of legal rules aimed at modifying behavior depend on the underlying model of human action.

Of these models of human action, the one that holds perhaps the greatest sway in modern legal thought is the model of rational choice. This model sees human behavior as governed by an assessment of different courses of action and deliberative, reasoned choice among these alternatives. From this conception of choice flows the moral and legal condemnation of negligence or intentional harm, and the justification for attaching legal consequences to a failure to live up to contractual promises or statutory duties. Only when behavior is understood to be the product of deliberate choice is it possible to find conduct blameworthy or to hold out the expectation that legal consequences can influence conduct.

The idea of deliberate, rational choice is thus of importance in almost every field of law. In contract law, however, the idea takes on constitutive importance: The very obligations that an individual is under in contract are a product of that individual's choice. Indeed, this principle is what distinguishes contract from tort. In contract, one is obligated only if one chooses to be obligated. In tort, one is obligated regardless of one's desire to be obligated; the only choice is whether or not to run afoul of the obligation.

Or, at least, so goes the conventional doctrine. The idea of choice as the source of obligation in contract has come under scrutiny from a variety of scholars, most notably relational contract scholars and critical theorists such as feminists. Grant Gilmore, for example, announced in 1974 the "death of contract" as a distinctive mode of obligation" -if obligations in "contract" arise from considerations of reliance or unjust enrichment, from fairness or justice, rather than from the will of the contracting parties, as Gilmore observed they do, then contract is not contract; it is tort. ${ }^{2}$ For relational contract scholars, modern contract law poses this puzzle: Is it possible to accept the idea that obligations arise from the norms of a contractual relationship without conceding the death of contract, of "choice"? For feminist contract scholars, the question is this: Is it possible to protect women from the oppressive consequences of

1 See Grant Gilmore, The death of Contract (1974).

${ }^{2}$ For an illuminating historical treatment of this issue, see JAMES GORDLEY, THE PHILOSOPHICAL ORIGINS OF MODERN CONTRACT DOCTRINE (1991). 
harmful, constrained choices-in surrogacy or marital separation agreements, for example-without divesting women of agency? In all these instances, the idea of what it is to choose comes to the fore.

In this Article, I examine how our underlying conceptions of what it is to choose animate legal reasoning in contract. In particular, I contrast the economist's conception of rational choice-which I consider to be a sharply delineated representation of dominant legal conceptions of rational choice-with Elizabeth Anderson's conception of rational choice. ${ }^{3}$ Building on the ideas that values are plural, incommensurable, and socially mediated, and that choice is rational when it is adequately expressive of values, Anderson constructs a vision of what it is to choose that is a substantial challenge to the dominant conceptions that undergird conventional contract logic. In doing so, I argue, she provides the basis for reconceptualizing choice in contract law in a way that should alter radically our understanding of the source of contractual obligation.

In particular, I defend in this Article the following claim. Conventional contract logic rests on the idea that when someone makes the choice to enter into a contract, she does so primarily to select a preferred future state of affairs; enforcement of the contract is then seen as a neutral act on the part of the law, which merely gives to the chooser what she chose. If we adopt Anderson's view of what it means to make a choice, however, this logic no longer applies. For in that vision we admit the possibility that the chooser assessed her options in light of what the choice would express rather than what future states it would secure. That is, the conventional logic is flawed when it asserts that the chooser has, necessarily, by deciding today to contract, indicated her choice among future states of affairs. Rather she has indicated her choice among current states of affairs; the choice among current states has consequences for the future only if the law attaches them. Analytically, Anderson's challenge to conventional rational choice theory raises a question that conventional contract logic thinks it has answered, namely, why does a person's choice at one point in time determine her legal obligations at another point in time? Why does a choice in contract have legal significance? It cannot be, after Anderson, simply because the law is a neutral arm of the state, handing out to contractors what they have asked for. Instead, the very problem of contract enforcement is that one of the contractors does not want what the state is giving.

\footnotetext{
s See ElIZABETH ANDERSON, VALUE IN ETHICS AND ECONOMICS (1993).
} 
Anderson's theory as applied here plays a negative role: It defeats an answer and thus begs an original question, but it does not answer it. It does not tell us that contracts should not be enforced or what the remedies for breach should be if a contract is enforced. Rather, I claim, it tells us that we need to identify reasons, beyond the bare fact that a choice to enter a contract has been made, for attaching legal significance to this particular exercise of choice. I suggest in this Article what some such reasons might be, and in particular, explore two: the protection of reliance interests and the protection of an instrumentally valuable convention. The principal point I defend, however, is that reasons for enforcement are needed, and I observe that turning to reasons such as reliance or convention would create a contract law that exhibits more differentiation among types of contract. Faced with the need in a given type of contract to identify a reliance interest or the instrumental value of a particular convention of contracting, we may be led to conclude that not all contracts are enforceable and, moreover, not all are enforceable in the same way or with the same remedy.

The Article is structured around a trio of feminist puzzles in contract law, but the claims of the Article are general and not limited in application to the puzzles. Rather, the puzzles are a device by which to reach the general claim I set out above. Each of these puzzleswhat to do about surrogacy contracts, marital separation agreements, and a wife's guarantee of her husband's business debts-poses what feminist legal scholars know as the "dilemma of choice," namely, the conflict between promoting women's autonomy and freedom of choice on the one hand, and protecting women from the harmful consequences of choices made under conditions of inequality on the other. ${ }^{4}$ I focus on these feminist puzzles not only for their intrinsic importance and interest, but also because they tap into and lay bare the core of what is problematic in contract law and logic more generally: the inadequacy of the conventional conception of rational choice. After exploring and comparing the conventional conception of rational choice and Anderson's reconceptualization of rational choice in generic terms, I revisit the feminist puzzles and discuss how our answers to the core questions of contract law-whether and to what extent a contract should be enforced-shift in light of Anderson's reconceptualization of what it means to choose ration-

'See, e.g., Gillian K Hadfield, The Dilemma of Choice: A Feminist Perspective on The Limits of Freedom of Contract, 33 OSGOODE HALL L.J. 337 (1995). 
ally. ${ }^{5}$ I conclude with some thoughts about how the analysis sheds light on the puzzles that motivate relational scholars and the currently obscured distinctions between commercial and other forms of contracting. A central conclusion is that Anderson's theory of choice preserves the bulk of conventional commercial contract law but provides insights into how contract works outside of this traditional core.

\section{FEMINIST PuZzles in CONTRACT: The DilemMa OF Choice}

What makes a case a puzzle in contract law is deep uncertainty about the right answer to two questions: Should a promisor be legally bound by her promise? If so, to what extent, that is, for what remedy should she be held liable? For feminists, these questions engage difficult issues in a variety of settings in which women make contractual choices. I analyze the three particularly salient puzzles mentioned above in light of the feminist dilemma of choice-the conflict between promoting a woman's agency in contract and promoting a woman's well-being when performance of a contract is harmful and serves to reinforce inequality and oppression.

\section{A. Surrogacy Contracts}

In a surrogacy contract, a woman agrees to relinquish at birth parental rights in relation to the child to whom she gives birth. In the most common form of such arrangements, the woman is the genetic mother of the child and the person to whom the child is relinquished is the genetic father of the child. In other arrangements, the woman is implanted with an embryo formed of the ovum and sperm of the people with whom she contracts; and in others the contract is formed between individuals none of whom has a genetic relationship with the child. $^{6}$

${ }^{5}$ I want to indicate at the outset that Anderson's book was itself motivated by the surrogacy puzzle and that she deals with what she sees to be the implications of her theory of rational choice for surrogacy in chapter eight. See ANDERSON, supra note 3, at 185-89. Anderson, however, approaches the problem as a question of policy and public law-should we permit surrogacy? My interest is in the implication of Anderson's theory for legal reasoning-in particular, contract reasoning.

${ }^{6}$ See Jaycee B. v. Superior Court, 49 Cal. Rptr. 2d 694, 696 (Ct. App. 1996) (noting that the sperm and the egg in this case were donated from anonymous individuals and then implanted into the uterus of a woman other than the intended legal mother). 
More accurately called contract pregnancy, ${ }^{7}$ these contracts raise two difficult questions. The first is a public-law question and is concerned with whether, as a society, we should permit individuals to contract for the conception of a child and the allocation of parental status. This question raises the specter of commodification, and feminists grapple with the implications for children, women, and sexuality of the use of market mechanisms to structure childbirth and parenting. ${ }^{8}$ The second question is a private-law contract puzzle. It is concerned with whether, in a given case in which the birth mother refuses to relinquish her parental status and in the absence of publiclaw prohibition, contract law should find that the birth mother has a contractual obligation to relinquish the child. Further, the second question asks whether any breach of this obligation should be remedied with an order of specific performance as opposed to an order for compensation.

The courts have struggled with the surrogacy puzzle originally made famous by the Baby " $M$ " case in New Jersey. ${ }^{9}$ Prior to reversal on appeal on public-policy grounds, the trial court in the Baby " $M$ " case held that the contract was enforceable and granted specific performance: termination of the birth (and genetic) mother's parental status. ${ }^{10}$ In Johnson $v$. Calvert, a case in which the birth mother was genetically unrelated to the child and the intending mother under the contract was the genetic mother, the California Supreme Court held that the intent of the parties as revealed by the contract was the "tie-breaker" under the Uniform Parentage Act that otherwise granted both the birth mother and the genetic mother parental status." As later interpreted by the California Court of Appeals, however, the Johnson case did not hold that such contracts are enforceable. ${ }^{12}$

${ }^{7}$ In the usual arrangement, the woman who gives birth is also the genetic mother and not a "surrogate" for a mother. She is perhaps a surrogate wife. I will use the term "birth mother" to refer to the woman who gives birth, whether she is genetically related to the child or not.

${ }^{8}$ For a discussion of commodification issues, see MARGARET JANE RADIN, CONTESTED COMMODITIES (1996). I review this book in Gillian K Hadfield, Book Review, 48 U. TORONTO L.J. (forthcoming 1998).

"See In re Baby "M," 525 A.2d 1128 (N.J. Super. Ct. Ch. Div. 1987), rev'd in part and aff'd in part, 537 A.2d 1227 (N.J. 1988).

${ }^{10}$ See id. at 1175 .

${ }^{11} 851$ P.2d 776, 783 (Cal. 1993).

${ }_{12}$ See Moschetta v. Moschetta, 30 Cal. Rptr. 2d 893, 900 (Ct. App. 1994) ("The most that can be safely extracted from the [Johnson] opinion is that gestational surrogacy contracts do not necessarily offend public policy."). 
The views of the majority and the dissent in Johnson clarify the conflict for feminists in these cases. As the majority stated:

The argument that a woman cannot knowingly and intelligently agree to gestate and deliver a baby for intending parents carries overtones of the reasoning that for centuries prevented women from attaining equal economic rights and professional status under the law. To resurrect this view is ... to foreclose a personal and economic choice on the part of the surrogate mother....

The dissent observed the other half of the dilemma:

Surrogacy critics, however, maintain that the payment of money for the gestation and relinquishment of a child threatens the economic exploitation of poor women who may be induced to engage in commercial surrogacy arrangements out of financial need. Some fear the development of a "breeder" class of poor women who will be regularly employed to bear children for the economically advantaged. Others suggest that women who enter into surrogacy arrangements may underestimate the psychological impact of relinquishing a child they have nurtured in their bodies for nine months.

The debate is paralleled in the feminist literature. Failure to enforce a woman's commitments is seen as a lack of respect for her as an autonomous agent. ${ }^{15}$ Yet, how is the feminist supposed to reconcile this endorsement of abstract autonomy with the situational reality expressed by some of the women who have served as surrogates, women who attest that, contrary to plan, the loss of the child at birth was experienced "like a death"? ${ }^{16}$ Feminist philosopher Virginia Held argues that the very idea of putting mother-child relations into a contractual structure, a structure that emphasizes autonomy, is to deny the reality of mothering:

To see contractual relations between self-interested or mutually disinterested individuals as constituting a paradigm of human relations is ..., many feminists are beginning to agree, to overlook or to discount in very fundamental ways the experience of women.

1s Johnson, 851 P.2d at 785.

${ }^{14}$ Id. at 792 (Kennard, J., dissenting) (citations omitted).

is See MiCHAEL J. TREBILCOCK, THE LimITS OF FREEDOM OF CONTRACT 51 (1993) (comparing women's autonomy in the contexts of abortion and surrogacy contracts); Marjorie Maguire Shultz, Reproductive Technology and Intent-Based Parenthood: An Opportunity for Gender Neutrality, 1990 WIS. L. REV. 297, 354-55 ("[T] he reality of sex discrimination is not a reason to presume categorically that women are unable to act freely and responsibly with reference to decisions about procreation and parental intentions.").

${ }^{16}$ For a graphic narrative about the experience of the first legal surrogate mother in the United States, see ELIZABETH KANE, BIRTH MOTHER (1988). 
…

A woman can have decided voluntarily to have a child, but once that decision has been made, she will never again be unaffected by the fact that she has brought this particular child into existence. ${ }^{17}$

Therein lies the dilemma: Do surrogacy contracts promote a woman's autonomy by recognizing her authority to contract, or do they perpetuate the error of ignoring what is real and fundamentally not governed by the norms of contract in women's experiences? Do they put a woman in charge of her life, or do they put her in the service of abstract principles that are at odds with what she knows to be true?

\section{B. Marital Separation Agreements}

Surrogacy poses the dilemma between the autonomy of contractual choice and the harm of contractual enforcement in stark terms. Generally, the dilemma is present in less stark terms in other settings. One such setting that has received substantial recent attention from Canadian courts is the marital separation agreement.

The dilemma is typically presented by marital separation agreements that fail to balance the financial needs of one spouse with the financial resources of the other. The Canadian Supreme Court addressed this issue in Pelech v. Pelech. ${ }^{18}$ The case involved a couple who divorced in a jurisdiction that did not, at the time, provide for the sharing of matrimonial property between spouses. They were married for fifteen years, during which time Mrs. Pelech, in addition to raising two children, worked as a receptionist and bookkeeper for her husband's general contracting business. The trial court found that Mrs. Pelech suffered from severe psychological problems, and awarded custody of the couple's two children to Mr. Pelech. Although the trial court granted Mrs. Pelech permanent maintenance, she subsequently agreed to accept a lump sum payment of $\$ 28,760$ in lieu of the awarded maintenance. Fifteen years later, Mrs. Pelech sought an order for spousal support, despite her contractual waiver. At that time, she was "living at a poverty existence level."'19 Due to physical and psychological problems, she was unable to work; she had exhausted the funds received at divorce; and she received welfare

${ }^{17}$ Virginia Held, Non-contractual Sociely: A Feminist View, in SCIENCE, MORALITY \& FEMINIST THEORY 111, 113, 126 (Marsha Hanen \& Kai Nielsen eds., 1987).

${ }^{18} 38$ D.L.R.4th 641 (1987).

${ }^{19}$ Id. at 645 (quoting lower court opinion). 
payments of $\$ 430$ per month. Mr. Pelech, in contrast, had accumulated a net wealth of $\$ 1.8$ million. ${ }^{20}$

In an opinion written by Justice Wilson, the first woman to sit on the Canadian Supreme Court and an acknowledged feminist, the Court held that even though the court retained the jurisdiction to award and vary maintenance, separation agreements must be enforced absent "a radical change in circumstances flowing from an economic pattern of dependency engendered by the marriage." The Court based this result squarely on the need to respect choices, particularly women's choices. ${ }^{22}$

In the years following Pelech, Canadian courts have continued to struggle with the finality of separation agreements. In Moge v. Moge, for example, the Supreme Court addressed the concepts of timelimited spousal support and self-sufficiency for divorced women. ${ }^{23}$ Justice L'Heureux-Dubé emphasized that the economic impact of traditional marriages-in which women sacrifice investment in their own earning capacity in order to maintain a household, raise children, and support their husband's investment in his earning capacity-carry on long past the marriage's end. ${ }^{24}$ This notion is evidenced by the dramatic changes in women's economic well-being following divorce, as compared to men's, and the overrepresentation of women among the poor. The Court concluded that the goals of the Divorce Act require support payments to continue indefinitely when the wife is unable to achieve economic self-sufficiency. ${ }^{25}$

Although Moge dealt with court-ordered support payments and not separation agreements, the impact of the Supreme Court's rejection of the self-sufficiency model is evident in the subsequent struggle to determine the weight that time-limited separation agreements should be given. For example, an Ontario court recently awarded spousal support to the wife in a twenty-three-year traditional marriage (she had a ninth grade education and a secretarial certificate; her

${ }^{20}$ See id. at $644-45$.

${ }^{21} \mathrm{Id}$. at 677.

${ }^{22}$ See id. at 675 ("I believe that [a] case by case approach and the continuing surveillance by the courts over consensual arrangement of former spouses ... will ultimately reinforce [gender] bias ....").

${ }^{23} 99$ D.L.R.4th 456, 462 (1992) (ordering "spousal support of $\$ 150$ per month for an indefinite period").

${ }^{24}$ See id. at 487 ( $[$ [I]n many cases a former spouse will continue to suffer the economic disadvantages of the marriage and its dissolution while the other spouse reaps its economic advantages.").

${ }^{25}$ See id. at 499. 
husband had earned a Ph.D. during the marriage and was now a professor) despite the fact that she previously had agreed to waive all future rights to support. ${ }^{26}$ The "package," as the parties referred to it, included provisions relating to the matrimonial home, child custody, and support, and gave the wife $\$ 1400$ per month for two years. ${ }^{27}$ The agreement, signed with legal advice, stated: "Thereafter, regardless of her situation, the wife will forever be responsible for her own support, regardless of any change in circumstances, no matter how catastrophic such change in circumstances might be ... ${ }^{28}$ Following the divorce, the wife resumed studying in hopes of becoming a legal secretary. ${ }^{29}$ Three years later, she could not afford to pursue her studies further-rather, she worked sixty hours a week at two temporary jobs earning a total of $\$ 1700$ per month. ${ }^{30}$ The court held that her inability to obtain full-time employment was not contemplated by the parties at the time of the agreement, and that her change in circumstances related to a pattern of dependency in the marriage. ${ }^{31}$

This case presents the same dilemma as Pelech. As the dissent in Santosuosso observed: "It is difficult to imagine a separation agreement entered into on a more fully informed basis reflective of the highest level of propriety with competent legal advice being rendered before the agreement was signed. "32 Yet, Mrs. Santosuosso's plight is hardly unusual. Against the backdrop of the economic realities facing divorced women-realities that the Moge court held must be taken into account in determining the financial obligations of a former husband in the absence of a separation agreement-and the evident failure of some separation agreements to take them into account, the price of respecting women's autonomy and "encourag[ing them] to take responsibility for their own lives and their own decisions," that women are left to bear the full brunt, including potential poverty, of their now wasted marital investment.

\footnotetext{
${ }^{26}$ See Santosuosso v. Santosuosso, 32 O.R.3d 143 (Gen. Div. 1997).

${ }^{27}$ See id. at 145.

${ }^{28} \mathrm{Id}$.

29 See id. at 155.

so See id. at 155-56.

${ }^{31}$ See id. at 156.

${ }^{32}$ Id. at 160 (Browne, J., dissenting).

${ }^{33}$ Pelech v. Pelech, 38 D.L.R.4th 641, 676 (Can. 1987).
} 


\section{Spousal Guarantees}

The dilemma of agreements between spouses is even sharper when those spouses are negotiating something other than the dissolution of their marriage. Whereas separation agreements are reached against a background of settled law, agreements during marriage operate in a virtual legal vacuum. Indeed, the issue of intramarital agreements rarely arises, but when it does, the courts struggle with the nature of such contracts. ${ }^{34}$ In a series of recent decisions, the British courts have confronted the dilemmas posed when a wife agrees to pledge the matrimonial home to guarantee her husband's business debts.

The issue often takes the form presented in Barclays Bank $v$. O'Brien. ${ }^{35}$ In that case, Mr. O'Brien sought a second mortgage on the family home as security for debt incurred by his company; that process required the consent and signature of his wife. The bank obtained her signature without explaining the document and she signed it without reading it, relying upon her husband's underrepresentation of the potential liability involved. When the bank eventually foreclosed on the mortgage, Mrs. O'Brien argued that the bank could not enforce the mortgage obligation because she had signed the agreement as a result of the undue influence or misrepresentation of her husband. ${ }^{36}$ The House of Lords held that the bank, having failed to take reasonable steps to ensure that Mrs. O'Brien had "entered into the obligation freely and in knowledge of the true facts," was charged with constructive notice of the husband's undue influence or misrepresentation and, therefore, could not enforce the obligation. ${ }^{37}$ The court also held that absent unusual circumstances, "a creditor will have taken such reasonable steps to avoid being fixed with constructive notice if the creditor warns the surety ... of the amount of her potential liability and of the risks involved and advises the surety to take independent legal advice."

3 See, e.g., Balfour v. Balfour [1919] 2 K.B. 571, 574 (Eng. C.A.) (stating the traditional doctrine that intramarital agreements are unenforceable unless there is clear evidence the parties intended legal obligation).

${ }^{35}$ [1993] 4 All E.R. 417 (H.L.).

${ }^{36}$ See id. at 421.

${ }^{37}$ Id. at 431.

ss Id. at 431-32. 


\section{The court in O'Brien recognized both sides of the dilemma:}

[S]ociety's recognition of the equality of the sexes has led to a rejection of the concept that the wife is subservient to the husband in the management of the family's finances. A number of the authorities reflect an unwillingness in the court to perpetuate law based on this outmoded concept. Yet... although the concept of the ignorant wife leaving all financial decisions to the husband is outmoded, the practice does not yet coincide with the ideal.... The number of recent cases in this field shows that in practice many wives are still subjected to, and yield to, undue influence by their husbands. Such wives can reasonably look to the law for some protection when their husbands have abused the trust and confidence reposed in them.

$\ldots$...

... [T] he sexual and emotional ties between the parties provide a ready weapon for undue influence....

But although the court recognized the dilemma, it did not resolve it. For a woman who is truly the victim of her husband's wielding of sexual and emotional ties as a "ready weapon," all the independent legal advice in the world cannot overcome the fear that she will damage the relationship with her husband if she opposes his wishes. Although it provides banks with a safe harbor, the rule does not accomplish what logically the court said it must, namely "satisfying [the creditor] that the surety entered into the obligation freely." The solution is a logical remedy for the problem of marital misrepresentation; it is not a remedy for the complex "sexual and emotional" factors that produce marital "agreements."

Thus, the dilemma remains. On the one hand, the complexity of the relationship between husband and wife (or, as the House of Lords explicitly recognized in O'Brien, between any cohabitees with an emotional involvement) makes plain the risk that a wife asked to guarantee her husband's debts ${ }^{41}$ will agree to do so out of subservience or

\footnotetext{
s9 Id. at 422,424 .
}

${ }^{40} I d$. at 431 .

11 The House of Lords has drawn a sharp distinction between the cases in which the security is given against a husband's business debts and when it is given against a joint loan to the couple. See CIBC Mortgages v. Pitt [1993] 4 All E.R. 433, 437 (H.L.). As Megan Richardson has emphasized, however, the distinction is weak. See Megan Richardson, Protecting Women Who Provide Security for a Husband's, Partner's or Child's Debts: The Value and Limits of an Economic Perspective, 16 LEGAL STUD. 368, 371 (1996) ("[I] t cannot be assumed that [the wife in $\left.O^{\prime} B r i e n\right]$ had no interest in a loan made to a company whose business supported the family income. In Pitt, on the other hand, the facts demonstrate that, even in the case of a joint loan contract, the woman may be only nominally a borrower with no real role in dealing with the money."). 
dependency, providing "another. expression of the already existing imbalance of economic, social and political power within the family." need of "tender treatment" and that such treatment may be institutionalized in the form of banking procedures. Many women would take as an insult to their competence the instruction that they (but not their husbands) must obtain legal counseling before a bank will contract with them. For some, indeed, it may rise to the level of sex discrimination to require that women but not men incur the cost of legal advice.

\section{The Dilemma in Contract Logic}

Each of these cases-surrogacy contracts, separation agreements, and spousal guarantees-is a puzzle for contract law because of contract law's understanding of choice. Contract law proceeds from the premise that obligation is established by the existence of voluntary and informed choice to enter into a contract. Hence, the defenses to the enforcement of a contractual obligation must demonstrate a defect in the circumstances of choice: a failure of voluntariness or an absence of adequate information.

In the surrogacy cases, for example, in the absence of publicpolicy limitations, a birth mother seeking release from the obligation to surrender parental status must demonstrate that she was coerced into the agreement or that she was mistaken about her ability to resist forming a maternal bond with the child. Her success under these doctrines is unlikely if the courts apply the same standards they apply in ordinary contract cases. The "coercion" a surrogate mother is likely to have experienced is the coercion of poverty or limited means that would not release her from any other contractual obligation. The mistake she makes is a unilateral mistake about the future and therefore not one she easily can shift onto the other contracting parties. Nor is she likely to succeed with an unconscionability argument that falls short of a public-policy finding that it is always unconscionable to extract an agreement from a woman to surrender for a fee a child to whom she gives birth. ${ }^{43}$

42 Richardson, supra note 41 , at 382.

${ }^{49}$ Instances of unconscionability are conceivable, particularly in light of stories about recruiting efforts made by surrogacy brokers. These brokers are lawyers who advertise for women to "enroll" in their surrogacy "programs" but who simultaneously act as the attorney for the intending parents. They thereby place themselves in a 
It is the unlikelihood of success with these contract defenses that, in fact, crystallizes the feminist dilemma. For if women were the beneficiaries of special doctrines of mistake or coercion, they would thereby be identified, in the logic of contract, as less competent, and more deserving of "tender treatment," than the autonomous agent with whom the law ordinarily deals. The spousal guarantee cases make this point plain. It is easy to imagine that some of the husbands in these cases are also acting out of complex motives related to gender inequality: the husband who is "coerced," for example, by his role as sole provider and the norms of masculinity to take on imprudent levels of debt to save his failing business. Yet, this husband will have no recourse in the courts, no protection from his "folly." The law does not presume that people always choose wisely or in their own interests. Indeed, it establishes that contract enforcement is neutral and that responsibility for the consequences of a foolish choice ordinarily lie with the chooser. When a woman seeks release from a harmful contract, she argues that she is exceptionally diminished in her capacity to assume responsibility for her choices. There's the rub.

In all three contract puzzles, the logic of contract is this: Contractual obligation only turns on the fact of voluntary and adequately informed choice. If voluntary choice exists, the contractual obligation exists, it is enforceable, and the courts are done. If consent was vitiated by coercion or mistaken premises, then the contractual obligation does not exist, and the courts are done. If asked why a given contractual obligation is enforced, the court's simple answer is, "she chose." The normative work is pared to a bare minimum: Once it has been established that the domain of contract extends, the judicial interest is only in the fact, not the wisdom, of choice. This is "freedom of contract"; this is neutrality in contract law.

fiduciary relationship with the intending parents but not the birth mothers who see the broker as their "employer." Unconscionability findings in circumstances such as these, however, likely will lead only to organizational changes, as the roles of lawyer and recruiter are unbundled and fees allocated accordingly. The core of the dilemma of surrogacy is unmoved by such changes.

4h This is evident in the debate over substantive versus procedural interpretations of unconscionability doctrine. See E. ALLAN FARNSWORTH, CONTRACTS $\S 4.28$, at 33235 (2d ed. 1990). Substantive unconscionability doctrine is "interference" with freedom of contract, a limitation on the court's willingness to enforce a contract based solely on the court's assessment of inequality in the bargain. Procedural unconscionability is not interference with freedom of contract. It is the perfection of the idea: Only those contracts reached under conditions that reasonably ensure that a party entered into a contract willingly and knowingly are enforceable. 
But is this how "contract" must work? It may seem so, by definition. If it is so, then women are indeed caught in the dilemma: Ei- . ther they are competent contracting agents or they must plead incapacity or vulnerability of one sort or another. It is the logic of this definition of "contract" that I want to question.

I will develop this idea further in the following sections, but at this juncture I want only to identify an alternative logic, one that does not turn exclusively on the fact of choice. Helpful in this analysis is an appeal to a category of existing cases, indeed the category to which Grant Gilmore primarily appealed when he announced the "death of contract." These are the promissory estoppel cases, summarized in section 90 of the Second Restatement of Contracts.

Promissory estoppel doctrine holds that a promise that is intended to be relied upon or that reasonably can be expected to induce reliance is enforceable if and to the extent justice requires. ${ }^{45}$ It represents a challenge to the core of contract law precisely because the enforceability of the promise does not turn solely on the fact of whether an individual chose to be obligated. The answer to the question of whether this contractual obligation should be enforced is not the simple, "she chose." Having established a voluntary choice about obligation (the making of a promise intended to be relied upon), the court still has work to do before contractual obligation is established. For even such a voluntary choice will only be enforced after the court has assessed the nature of reliance and inquired into what justice requires. Moreover, the court will have to determine the extent to which the obligation should bind-that is, the remedy that justice requires. In the ordinary contract case, of course, the remedy follows once the obligation is found: The plaintiff is entitled to be put in the position she would have been in had the promise been performed,

45 English/Canadian doctrine limits the application of promissory estoppel to those cases in which the promise is a modification of existing legal relations. The doctrine can be stated as follows: A promise that is intended to alter legal relations, intended to be relied upon, and in fact relied upon, is enforceable where it would be inequitable to allow the promisor to revert to the prior legal relationship. See D. \& C. Builders, Ltd. v. Rees [1965] 3 All E.R. 837, 843 (C.A.); Combe v. Combe [1951] 1 All E.R. 767, 768 (C.A.); Central London Property Trust Ltd. v. High Trees House Ltd. [1947] 1 K.B. 130, 134 (1946).

The American doctrine is given in section 90 of the Second Restatement of Contracts: "A promise which the promisor should reasonably expect to induce action or forbearance on the part of the promisee or a third person ... is binding if injustice can be avoided only by enforcement of the promise. The remedy granted for breach may be limited as justice requires." RESTATEMENT (SECOND) OF CONTRACTS $§ 90(1)$ (1973). 
usually through monetary compensation. In the promissory estoppel cases, the remedy may be restitution, reliance, or expectation. ${ }^{46}$

The point is that an alternative contract logic, in the way I am using these ideas, is a contract logic that asks more than whether one has made a voluntary choice to obligate herself. The issue is not whether she chose to be obligated; rather it is what the legal significance of her choice to be obligated should be. An essential difference from tort law nevertheless exists. In tort, the obligation is imposed irrespective of an individual's desire to be obligated. In contract, as reconceived in section 90 , if an individual is obligated it is because she chose to be obligated and the court found reasons to attach legal significance to that choice. ${ }^{47}$ The self-created nature of the obligation is still necessary, but it is no longer sufficient.

Put bluntly, the reconceptualization of contract law that I am aiming at responds to the short answer "she chose" with "so what?" This is where the conceptualization of rational choice enters the picture. The adequacy of the answer "she chose" and the need for the followup "so what" depend on the underlying conception of what it means to say "she chose." The dominant conception of rational choicewhich I will explore in terms of the economic conception of rational choice as an exemplar-makes "she chose" seem like an adequate answer. Elizabeth Anderson's conception of rational choice-of choice as expressive of pluralistic and incommensurable valuesmakes the follow-up "so what" essential.

\section{COMPETING CONCEPTIONS OF CHOICE: ANDERSON AND THE ECONOMISTS}

In this Part, I compare the dominant conception of rational choice, as exemplified by the economic conception, with Elizabeth

${ }^{46}$ See RESTATEMENT (SECOND) OF CONTRACTS $\$ 90$ (1973).

${ }^{47}$ There is a bit of a red herring here, namely the objective theory of contract. Although it is true that contractual obligation attaches on the basis of manifest intent to be bound, rather than a subjective state of mind, this is thought of as an "imperfection" due to the inability to observe mental states. The classical will theory of contract, which is what is played out in the ideas that animate the core of modern contract doctrine, is based on the idea that obligation arises because of the subjective decision to be obligated. The incoherence of the will theory and the ways in which modern contract doctrine depends on more complex ideas than that of the will of the contracting parties are beyond the scope of this Article. See Abraham Drassinower \& Gillian K. Hadfield, Beyond Contract as Promise and The Death of Contract: A Relational Theory of Contract (Apr. 1997) (unpublished manuscript, on file with the University of Pennsyluania Law Review). 
Anderson's challenge to this conception. I demonstrate that the dominant conception animates the idea in contract law that the fact of choice is sufficient to ground contractual obligation, but that under Anderson's conception of rational choice, the fact of choice is not sufficient to ground contractual obligation. Such an insufficiency requires that the work of the courts must extend beyond "she chose." As a consequence, the feminist dilemma of choice dissolves under Anderson's theory, and we are led to a different approach to resolving the contractual puzzles posed by surrogacy, marital separation agreements, and spousal guarantees.

\section{A. Two Preliminary Distinctions}

Before embarking on the discussion of these competing conceptions of choice, I want to clarify the nature of this project by emphasizing two distinctions: first, the familiar distinction between positive and normative aspects of theory, and second, the distinction between instrumental and agent-centered theories of contract enforcement.

On the first distinction, my interest in economic theory in this Article is in the positive aspects of the theory. It is not my intent to appeal to economic criteria, such as efficiency, in order to answer the normative questions of contract law regarding whether a promise should be enforced and what the remedy should be. Rather, I am interested in how the conceptual and descriptive aspects of economic theory animate the normative reasoning that exists in contract doctrine. The normativity here is the self-conscious normativity of contract doctrine, the way contract doctrine establishes normative propositions and reaches normative conclusions. ${ }^{48}$ When the picture of choice that runs through our minds is that of a rational economic man, how do we approach the doctrinal questions of contract law on contract law's own terms? My purpose in exploring Anderson's alternative conception, then, will be to demonstrate that when we change our understanding of what it means to choose, we change our understanding of contract logic. The economic conception supports the logic that contractual obligation follows from the fact of choice; Anderson's conception contests that logic as insufficient, and sup-

49 This is exceedingly difficult to pin down, of course. There is overt contract logic-the meeting of the minds, manifested intent, the reasonable contemplation of the parties, and so on-and there is the covert logic of values and extraneous decisionmaking principles (like fairness, punishment, and so on). When I refer to the selfconscious normativity of contract law, I mean the normativity that emerges from the interplay of dominant and subversive reasoning in contract doctrine. 
ports a logic that requires additional reasons, beyond the mere fact of choice, for contractual obligation to bind.

These ideas will be clarified if we also hold up the distinction between instrumental and agent-centered theories of contract enforcement. An instrumental approach to contract enforcement asks whether we should enforce promises in order to achieve social goals. Enforcement in a given instance is then just the implementation of a desirable institution; justification is centered on the institution, not the individual case. An agent-centered approach to contract enforcement asks whether we should enforce this promise, and does not accept an answer that merely restates the justification for enforcing promises generally.

Some examples will elucidate this distinction. Normative economic analysis asks whether social wealth or welfare is increased by the enforcement of contractual promises. This approach is instrumental and institution-centered. A contract rule-such as the rule of expectation damages as a remedy for breach-is thought to be welfare-maximizing; thus, in a given instance, expectation damages are awarded in order to implement an efficient rule. This is instrumental reasoning; the particular agent against whom the award is made is not given any reasons for being held liable. There is no reliance on the agent's interests in this reason. ${ }^{49}$ Her conduct may trigger application of the rule, but it is not the source of the obligation.

An agent-centered justification for enforcement, by contrast, addresses the particular agent and says, for example, "you are obligated to pay expectation damages because fairness or corrective justice requires that you not renege on the promise to bestow the promised value on your contracting partner." These reasons are addressed to the agent-the obligation is founded in her conduct, not merely triggered by it. These reasons are potentially persuasive to the individual-fairness or corrective justice is a principle to which she should hold herself and to which, in any event, the law will hold her.

The distinction between instrumental and agent-centered justifications can be illuminated further by appeal to John Rawls's treatment of the morality of promising. ${ }^{50}$ Rawls argues that for instru-

${ }^{19}$ This is so even if the efficiency criterion we are using at a given point is Pareto efficiency, which ostensibly takes the agent's interests into account. Even here, however, we are saying to the agent, we are reaching this result because it will not make anyone (including you) worse off and will make someone (perhaps you) better off; still, the obligation flows from our judgment that this is a good criterion to apply.

${ }^{50}$ See JoHN RAWLS, A THEORY OF JUSTICE 34448 (1971). 
mental reasons, a convention of promising is valuable because it allows people to rely on one another and hence achieve more efficient goals than they otherwise could. The convention itself is not required by the principles of justice, but once established, the promises are binding. Why? The purely instrumental answer is that in order to achieve its valuable goals, the convention of promising requires that promises be binding. Rawls, however, having justified the convention on instrumental grounds, moves to an agent-centered justification for the application of the convention to an individual: A participant in the convention is bound to keep her promise because fairness requires that she who invokes a (just) convention and benefits from it must adhere to its rules. The justification is agent-centered because it does not rely exclusively on instrumental reasons for the convention itself. Rather, it introduces a new reason, a reason based on the fairness of the individual. A fair individual would agree that she is bound to play by the rules of a game she has chosen to play. ${ }^{51}$

The distinction between agent-centered and instrumental justifications for contract enforcement is important because contract logic ${ }^{52}$ is overtly agent-centered. Whereas normative economic analysis appeals to instrumental reasons for the rules of contract, courts deciding contract cases rely on agent-centered reasons. This is not to say that instrumental considerations, such as the impact of a particular rule on the cost of contracting, are not found in actual contract reasoning. Rather, the overt structure of modern contract lawobligation founded in conduct manifesting an intention to be bound, release from a contract for reasons of mistake or coercion-is agentcentered. Agent-centered reasons are dominant in that the instrumental considerations cannot stand if they are expressed as being in direct conflict with an agent-centered reason: Instrumental concerns about the cost of implementing a rule, for example, must yield if failure to implement the rule would vest obligation in the absence of manifest intention to be bound or in the face of clear coercion.

My project in this Article is to draw on the descriptive and conceptual features of rational choice theory in order to explore contract logic in its predominantly agent-centered form. Hence, when I ask whether we should enforce a contract, and I explore the role of the economic conception of choice in the answer contract logic gives to

51 See id.

32 "Contract logic" refers to the resolution of the questions of contract law within the terms of contract doctrine. 
that question, I diverge from the instrumental, normative response of economic analysis. The answer to the question of whether we should enforce a contract must, within contract logic, address the agent involved. I want to explore how differing conceptions of rational choice lead us to think that the reasons we give that agent are adequate or not. It is agent-centered contract logic that responds, "we enforce this obligation because you chose to be obligated." The adequacy of that answer is at issue.

\section{B. The Dominant Paradigm: The Economist's Conception of Rational Choice}

For the economist, human activity is about making choices. An economic agent surveys the world and identifies various alternatives among which she has defined preferences; to be rational is to make choices consistent with these preferences. Preferences reflect an individual's instrumental assessment of the contribution of an alternative to her well-being, and rational choice involves selecting from alternatives based on their relative value to the individual. Rationality is consistency and transitivity: If you prefer $X$ to $Y$ and $Y$ to $Z$, then rationality requires that you prefer $X$ to $Z$ and choose accordingly.

For the rational economic agent, therefore, choice is a rather banal affair. It is complicated only to the extent that the agent needs to process large quantities of information in order to determine the benefits in utility terms of alternative courses of action. Should she go to law school or try her hand at writing novels? The answer results from collecting and processing information about anticipated costs and returns (including psychic ones) from both types of employment. Assuming this information is available, the agent who vacillates over her choice does so because she has nothing to lose from choosing one alternative over the other; the only reason for indecision is indifference. Even if the information is not fully available, it is presumed that the agent evaluates different options and then acts rationally in accordance with her expected utility function.

The economist does not presume to tell an agent how to evaluate options; the economic view of value is a subjective one. Nor is it the case that the economist rejects values that reflect an individual's concern for others. If our would-be novelist/lawyer places a high value on law school because she believes her success there will make her parents happy or enable her to afford a larger home for her children, nothing is at odds with the economist's model. Indeed, the economist is distinctly uninterested in the source of an individual's subjec- 
tive preferences. All that matters is that the individual has stable and internally consistent preferences establishing an ordering over alternatives, and that she chooses according to them.

The economist qua economist is neutral with respect to an individual's preferences, but this does not mean that the law must be neutral as well. Viewing an individual through the economist's lens of rationality, indeed, allows the law to make judgments about individual preferences and choices. Driving carelessly, for example, is a choice an individual makes based on an assessment of her perceived costs and benefits. It is perfectly consistent with the rational choice model to condemn this person for judging the costs of her behavior to be low relative to the benefits, and to mandate that the individual who makes this choice should bear the consequences of her behavior. It is also perfectly consistent to conclude that, by attaching legal consequences to this choice, the law might cause the individual to choose differently.

The economist's neutrality with respect to preferences is the basis for a normative stance in law that adopts neutrality and endorses legal regimes that promote the exercise of free choice. Neutrality is also the important connection between conventional contract logic and the economist's conception of rational choice. As seen from the perspective of rational choice theorists, contracting is simply about making decisions so as to produce future desired outcomes. Choosing to commit oneself through contract is a rational choice like any other, relying on an assessment of the costs and benefits of present and future consequences of this contract as contrasted with another contract or no contract. Law that enforces contractual choices thus maintains its neutrality with respect to the underlying options and relies on the parties' own assessments about value at the time of contracting. The law holds an individual to her side of a contract because that is what she chose.

The key observation here is that the simple logic of "she chose" is animated by the image of choice in contract as an instrumental selection from alternative future options. It assimilates the choice of a future course of conduct and outcome with a contemporaneous choice. "She chose" does not distinguish, fundamentally, between choice among present alternatives and choice over the future. Nor does the economist's conception of contractual choice. "She chose" appears to be an adequate response to the question of why to enforce an obligation because the image of choice is the image of an individual pointing to what she wants in a shop window displaying tomor- 
row's goods. The question of why you give her this thing is then redundant, easily answered: "she asked for it."

Indeed, to refuse to give an individual what "she chose" is to treat her as a chooser of limited capacity; it is to accord her less respect than we accord free and rational beings. Charles Fried emphasizes this point as follows:

[To] respect those determinations of the self is to respect their persistence over time. If we decline to take seriously the assumption of an obligation because we do not take seriously the promisor's prior conception of the good that led him to assume it, to that extent we do not take him seriously as a person. We infantilize him....

This is a normative stance from which what matters for the law is whether or not one has chosen. Once we have established that, the normative work for the law of contracts is done. To engage in further normative inquiry into the content of the choice or the consequences that follow on the choice amounts to paternalism and a failure of respect. These consequences are the ones she chose according to her conception of the good.

Fried is not an economist, but, in an essential way, he envisions choice in the same way as the economist. He is collapsing contract choice-an act that has significance for future well-being-with contemporaneous choice. He is imagining contract choice as an assessment of an array of current options according to some private metric- "the good." Although he explicitly adverts to the fact that contractual choice is choice over time, he reduces the significance of time to the stability over time of preferences or conceptions of the good, a stability that defines maturity and mastery over the whims of childhood. As it is for the economist, choice for Fried is the implementation of stable preferences, so choice that is realized immediately and choice that is realized over time are essentially equivalent.

${ }^{33}$ Ian Macneil has emphasized this point from a different perspective in his writing on relational contracts. Adopting the descriptively accurate but linguistically cumbersome (and hence seldom-used) term "presentiation," Macneil argues that the error of standard contract analysis is the failure to recognize that not all contractual relationships are discrete transactions in which obligations are presentiated, that is, fully expressed at the moment of contracting; many involve complex ongoing relationships in which there will be future adjustments and modifications. See Ian R. Macneil, Restatement (Second) of Contracts and Presentiation, 60 VA. L. REV. 589, 590 (1974) ("Recognition of a present binding of the future, particularly verbalization of that recognition, inevitably lags behind the extent to which the future is in fact bound.").

${ }^{34}$ Charles Fried, Contract as Promise 20-21 (1981). 
In either case we give someone what she chose simply because, at some point, she chose it; the evaluative move was hers, not ours.

This collapse of contractual choice with contemporaneous choice is so familiar that it can be difficult to remember that it is not necessary. For although it may be appropriate, out of liberal deference to the individual's knowledge of her own desires, to give someone what she asks for in a contemporaneous sense, the fundamental problem of contract law is that the individual against whom the contract is being enforced is no longer asking for the same thing. Given the individual's change of mind, the original choice assumes significance only if the law gives it significance. Unlike the contemporaneous shop-window choice, the question of why to give a person what she chose is no longer redundant because there are two choices in front of us, separated in time. The question is, why does the earlier choice have any legal significance? The consequences of the earlier choice only follow if the law makes them follow. The birth mother loses her parental status, the ex-wife is denied her right to obtain spousal support, the bank is permitted to foreclose, only if the law requires it. These are legal consequences, not natural consequences. Why should these consequences be made to follow? The significance of this question comes into focus when we recognize the distinction between contemporaneous choice and contractual choice. Both the economist and Fried, however, collapse this distinction.

\section{Anderson's Conception of Rational Choice as Expressive Choice}

When the complexity of contractual choice is collapsed into the image at the shop window, critics such as the feminist begin to chafe at the degree of abstraction involved. Who are these people who populate the economist's and Fried's imaginations, who calmly assess the alternatives available according to a stable set of internally consistent preferences and proceed to select the obvious choice, who apparently feel no passion or emotion, who do not worry about whether they are choosing well, who never feel trapped by their choices, and who never discover over time more about themselves and their understanding of their choices? Where is love, duty, fear, self-doubt, and power? Fried's description of the appropriate stance of the law with respect to the exercise of contractual choice by free adults sounds more like Victorian moralism than a model of respect for others. The feminist dilemma lies in how to reject the implications of the economist's model of rational choice without adopting the position that women are not rational; that is, in Fried's view, infantile and 
ruled by emotion. This is the dilemma of choice, the apparently headlong confrontation between being an agent whose autonomous choices are respected and being an agent who seeks to avoid the legal enforcement of her choices.

Elizabeth Anderson's conception of rational choice offers, ${ }^{55} \mathrm{I}$ believe, a way out of this dilemma by providing a foothold to a contract logic that does not see the decision to refrain from implementing a person's earlier choice as a failure to respect her autonomy. Anderson's conception of rational choice captures a greater share of the human experience without relinquishing rationality. Indeed, she defines rationality as requiring the integration of emotion, relation, and the possibility of growth into the process of valuing and choosing among alternatives. Moreover, she recaptures for rationality attributes of community and public meaning, releasing rationality from its narrow confines within our separate skulls.

Anderson's conception of rational choice begins with the idea that valuation is both pluralistic and public. Consider pluralism first. Anderson argues that we value things or states of affairs in multiple ways. Love is a way of valuing something or someone; respect is another; revulsion another. These modes of valuation are not merely poetic terms for "more" and "less." Rather, they relate to distinctive human experiences and, importantly, to social concepts of valuation. To say that I admire your musical talent, for example, is not merely to say that I derive a certain sum of pleasure from knowing you or learning of your latest accomplishments. As the complexity and subtlety of language reveals, taking pleasure in your accomplishments is a different attitude than admiration. Nor can I necessarily say that enjoying the music you have performed is a greater or lesser value than admiring your ability to perform it.

What is essential about pluralistic valuation is the idea that different modes of valuation are incommensurate. This notion is clear from the fact that the focus in pluralistic valuation is on how something is valued-as an object of love, disgust, or respect, for example-rather than simply how much it is valued. In contrast, the economist requires that all valuation be ultimately commensurate, that the question "how much" always be resolved by a single answer. For rational choice, as we have seen, is nothing more for the economist than choice according to "how much."

${ }^{55}$ This discussion of Anderson's conception of rational choice is based on ANDERSON, supra note 3, at 1-90. 
Incommensurability, however, does not imply the impossibility of choice, of comparison between alternatives and selection among them. Anderson's theory is indeed a theory of choice-rational choice-among alternatives. But from her starting point in pluralistic valuation, Anderson's theory concerns the rationality of choice in light of the how rather than the how much of valuation. How does someone decide whether to stay for the duration of a concert or to leave early in order to meet a friend for a drink? If she values the performance and the date exclusively in terms of the enjoyment of the music and the company, if this is how she frames her choice-then she chooses which pleasure is greater at any moment in time. If she admires the musician, however, then she must take into account how leaving in the middle of the concert may fail to express her admiration. If she respects her friend, she must also take into account how choosing the concert over the date may fail to express her respect.

To Anderson, this way of approaching the choice is required by rationality. To be rational, according to Anderson, is to express one's values or, as she terms them, one's rational attitudes. What can it mean to say that someone admires a musician if she walks out of a concert as soon as she judges that she would enjoy her friend's company more? Can this action, this choice, be made sense of in light of the professed admiration? If not, then either this individual does not in fact admire the musician-does not value the musician or the concert in this way-or she is behaving irrationally.

The public nature of valuation and choice is evident in this formulation. The determination of what rationality requires in turn requires an appeal to social facts, norms, and understandings. To ask the question, "can it make sense to walk out on a concert if one admires the musician?" is to appeal to reasons that others might find sensible or persuasive. It is also to explore the social meaning of a term such as "admiration." Others may indeed differ greatly on their perception of the meaning of the terms used, but it is quintessentially irrational to act in ways or according to a language that make sense to no one else. We doubt the rationality of those whose reasons and perceptions of reality are utterly idiosyncratic.

Importantly, for Anderson, what counts as a rational expression of valuation is itself the subject of reasoned discussion. We cannot say, in isolation, this act is or is not rational. Rationality will depend on both the individual's perceptions and the communities in which she moves. It will depend on the frame in which a given choice is evaluated, and this frame is itself subject to reasoned dialogue with oneself 
and others. Walking out on the concert may make sense at an openair festival with continuous or multiple performances; it may not at an elegant concert hall. It may make sense in some communities or cultures and not in others. Perhaps more importantly, through reasoned discussion, we may be able to persuade each other that rationality requires a different valuation than we used to think. Indeed, much persuasion is aimed towards changing the frame a decisionmaker brings to her choice. We might, for example, attempt to alter the view of a concert-goer who feels it would be disrespectful to walk out to join her friend merely to enjoy her friend's company. In doing so, we urge the decisionmaker to see differently what values are at stake in a given choice. Discussions with others or self-reflection are helpful precisely when they recast a difficult choice in a different light. It is a matter of looking at a problem in the right way, and not merely deciding it rightly. That, to Anderson, is rationality in choice.

Anderson's conception of value is also subject to the demands of rationality. Anderson speaks of valuation as the holding of rational attitudes towards individuals, objects, or states of affairs. Valuation itself, then, has important public dimensions. Through reasoned discussion with others, we may discover that it is not rational to feel admiration or respect or revulsion towards someone or some thing. Valuation is subject to development and change in response to reflection and dialogue. What is inscrutable to the economist is, for Anderson, necessarily the object of potential scrutiny. ${ }^{56}$ Valuation may be the province of subjectivity, but subjectivity, in Anderson's view, is only rational to the extent that it subjects itself to objective tests. Thus, Anderson argues that a measure of doubt about one's values and choices is rational. To be rational, our preferences must be justifiable to us.

Anderson's theory of rational choice also recognizes that our valuation and choices are, in many respects, constitutive of who we are and how we develop as individuals and as communities. Valuation and choice are rational, at least in part, because of their relationship to a coherent understanding of ourselves and our relationships to others. Choices are not just about achieving consequential goals, such as income. They are about defining and becoming who we are.

${ }^{56}$ Anderson does allow that there are categories of goods that are valued in exclusively consequential terms based on inscrutable tastes. But whereas the economist takes all valuation as tastes in this regard, Anderson sees this as properly understood as a subset, and a relatively small one at that. Not all, or indeed many, choices in life are like the choice between flavors or colors. Life is not a bowl of ice cream. 
Choosing to stay in a job in which we are harassed, for example, may be a choice grounded in self-conception. Perhaps this choice confirms our view of ourselves as tough individuals who will not be intimidated. Perhaps we stay because we lack self-respect and perceive ourselves as deserving of degradation. Perhaps, instead, we think of ourselves as "nice girls" rather than "strident feminists." In sum, our valuation of the state of affairs and our resultant choices are ways in which we weave the narrative of who we are and what we value. It is in this sense that Anderson's theory sees value and choice as expressive, not merely instrumental.

In a related vein, Christine Korsgaard has argued that moral conduct is normative in that, as self-reflective beings, we look for reasons we should act in a given way. Those reasons come from our having and maintaining coherent identities. ${ }^{57}$ This makes plain Anderson's notion that choice is often fundamentally about expressing and maintaining a coherent sense of self. I choose this way because that is who I am. Through reasoned reflection and dialogue, I now may choose differently because I see that this is a better understanding of who I am and who I should be.

What is banal in economic analysis-the determination of value and the selection from alternatives according to values-is thus central to Anderson's conception of rational choice. Valuation and choice are the subjects of self-reflection, shared meanings, dialogue, and growth. To focus on the rationality of results, measured by their concordance with a fixed set of given preferences, is to miss the essence of the struggle to be rational, the process of finding rationality.

\section{EXPRESSIVE RATIONAL CHOICE: RESOLVING THE FEMINIST DILEMMAS}

Conventional contract logic views contract law as a realm of purely private ordering in which individuals are free to choose the structure of their relationships without interference. In this view, law does not judge the formation, performance, or breach of a contract on the basis of external juristic values; law acts only as a surrogate for the values created by the parties themselves. The implication of the economic (and, more generally, the liberal) understanding of choice as a purely private matter is judicial indifference toward the making-

${ }^{57}$ See Christine Korsgaard, The Normative Question, in THE SOURCES OF NORMATIVITY 7, 18 (Onora O'Neill ed., 1996) ("[Moral claims] must issue in a deep way from our sense of who we are."). 
and breaking -of contracts. Since value is subjective, no basis exists for the law to judge the choice of one form of contractual relationship over another. ${ }^{58}$ Nor is there a basis for judging the decision to alter a contractual relationship, whether consensually or unilaterally, through breach. Law aims exclusively to give effect to the arrangements and to protect the interests voluntarily created by contracting parties. This legal treatment of contracts, based on an economic model of rational choice, treats contract as purely a private matter. Hence, a contracting party has only herself to blame for the consequences of her contract since the contract and its obligations are entirely the product of her choice.

Anderson's conception of rational choice as expressive choice can endorse the idea that contracts are private orderings, but it disrupts the judicial indifference to contractual consequences that follows in the conventional logic. For an expressive choice to enter into a contract may spring not from an assessment of the value of future consequences, but rather from a person's judgment that, in the present moment, signing a given contract adequately expresses her valuation of a situation, another person, or herself. She may not have pointed at a particular good in the shop window because she judged it the best from the array offered, but rather because respect for the shopkeeper or disgust with herself required it. Thus, her choice may have been fundamentally an expression of her valuation of the present circumstances and not an expression of her consequential assessment of future options. She may have chosen to make a promise as an end in itself rather than as an instrument to bring about some future state of affairs.

If the reason for pointing at the goods in the window was presentoriented and not made with a view to choosing a desired future-if the promise-making was expressive and not instrumental-what is the rationale for requiring a state of affairs to follow if, when the future comes, our chooser now says she does not wish to choose accordingly? She did not choose that state of affairs; she chose the earlier state of affairs, and that earlier state determines the later state only if the law makes certain consequences follow. The question Anderson's picture of expressive choice demands an answer to is "why should these consequences be made to follow?"

${ }^{58}$ Public policy, illegality, and substantive unconscionability, if the last exists, however, do provide limits. 
Anderson's picture does not tell us that there is no good answer to this question, but it does give the lie to the idea that it is adequate to answer simply, "well, she chose this future." She did not; she chose a present now past. The future state of affairs may or may not have been part of how she framed her choice. Incommensurability in choice makes it impossible to say that any choice she made must have been framed with a view to balancing the consequences of her choice. When we say that her past choice, however she framed it, is a choice of the future because she must be held to the consequences of her choice to contract, we beg the question. Instead, let us consider how contract logic based on Anderson's conception of rational choice would analyze the three feminist contract puzzles we have identified.

\section{A. Implications for Contracts: Surrogacy Begun}

If we adopt the economist's theory of rational choice, the decision to enter into a surrogacy contract is like any other choice. A potential birth mother assesses her personal preferences for the available options. She weighs the expected benefits of the income or satisfaction against the expected physical, emotional, and social costs. The woman who changes her mind about carrying through with the contract does so, on this theory of rational choice, for one of three reasons: (1) she is opportunistic and seeking to extort the father; ${ }^{59}$ (2) she erred in her calculation of the expected costs and benefits; or (3) she did not choose rationally to begin with, because of either diminished capacity or coercion. ${ }^{60}$

According to the conventional logic, the first reason is not grounds for letting the woman out of the contract. Neither is the

${ }^{59}$ This is Richard Posner's analysis:

[Without a legally enforceable contract] the father and his wife have no assurance that they will actually get a baby out of the deal. ... Even if the surrogate mother does not renege, she has an incentive to threaten to do so in order to obtain a higher price than the one she agreed to accept back when the contract was signed. In other words, if the law refuses to enforce contracts of surrogate motherhood, it empowers surrogate mothers to commit extortion.

RICHARD A. POSNER, SEX AND REASON 422 (1992).

${ }^{60}$ These latter possibilities are dealt with by Michael Trebilcock, who, while sensitive to the emotional and relational complexities of surrogacy, nonetheless stays within the economic conception of rational choice in his analysis. See TREBILCOCK, supra note 15, at 48-57 (examining problematic contracting cases, such as surrogacy contracts, using a market-failure approach). I compare Posner and Trebilcock on this score in Hadfield, supra note 4, at 339-47, and Gillian K. Hadfield, The Second Wave of Law and Economics, 46 U. TORONTO L.J. 181, 184-87 (1996). 
second reason, unless we find an extraordinary mistake. Both Fried's notion of autonomy and the fact that uncertainty is attendant on almost any choice lead us to the position that, unless there is something exceptional here, mere regret is no basis for release from the contract.

The third reason necessarily must be limited if we start with the economic model of rational choice. The economic model assumes that action is premised on rational choice and that coercion and irrationality are the exception and not the rule. Hence, law motivated by this vision of human behavior will look for extreme forms of coercion (rather than the ordinary coercion of gender or class) or irrationality. To do otherwise would be to unravel the core premises on which such law is built.

Therefore, what emerges from the economic model of rational choice is a replication of its one-dimensional view of the birth mother's choice to enter into a contract. The flattened landscape of her choice is mirrored by a flattened legal landscape. The economic model instructs the law to attend only to the instrumental, idiosyncratic weighing of options, and so, the legal consequences that attach to choice are modulated only by such considerations.

Moreover, the birth mother is isolated in the individuality of her choice: freedom from the community is also isolation from the community. Her choice is only about her subjective and inscrutable preferences, and so, there is no place for communal common concern or participation. When the economic conception of rational choice is applied to her choice, the features of the landscape that embody the relationship between her choice and her social context are flattened. The economic model cuts her off from the community and from the socially shaped meaning of her actions.

When we turn to Anderson's theory of rational choice, dimensionality and community return. A birth mother's decision to enter into a surrogacy contract may have been expressive of her values, and it may have been fundamentally directed towards expressing, at that point in time, how she saw herself in relation to the world: how she valued herself, pregnancy, money, her family, and the intending parents. Suppose her act is not best understood as a calculation of expected costs and benefits, but rather as a means of expressing the values of compassion and generosity towards those unable to bear children or an act expressing her valuation of her body as a source of life. Or perhaps it is an expression of self-hatred, of her devaluation of herself as a responsible mother. Or it may be an expression of her 
valuation of money as evidence of her degraded value to her family. Perhaps at the moment she decided to enter into that contract, she was struggling to express to herself, her family, and the world that she was valuable and worthy of respect.

Anderson's understanding of what it is to choose requires that we attend to the framing of choice by, and hence the meaning of choice to, the chooser. Anderson contests the economist's view that every choice is framed by every chooser as an instrumental assessment relative to some metric. If we accept Anderson's story of what it is to choose as being more accurate than the economist's, we cannot say the birth mother's contractual choice was a choice about the future. For her, it may have been a way of expressing something in the present. This is not to say that she was unaware of the future when she made the choice. But to interpret what the choice meant for the chooser, all we can say is that, at that moment, she chose to express her values in terms of statements about the future. It is the promise about the future, and not the future itself, that she valued. She may have assessed the future in consequential terms and chosen a promise because it would produce a future. But it is not, Anderson teaches, necessarily the case that the choice to promise was framed consequentially. In some situations, the promise may not be merely an instrument towards an end, but rather the end itself. Indeed, some decision frames, such as a punitive frame, which interprets the decision to enter into the contract as an expression of self-loathing, or a defiant frame, which interprets the decision as an expression of self-value in the face of economic need, may demand, by the very terms of the valuation they reflect, that the individual not attend to a set of future consequences. Some forms of valuation require that the chooser eschew certain considerations; unconditional love, for example, is just that.

And so, we cannot retreat easily from answering the question in the surrogacy case: Why should the decision to enter the contract govern the relationship between a woman and the child to whom she has given birth? What is, or should be, the legal significance of the fact that the birth mother signed a contract, one act performed among many others? Why and how should this affect the legal relationship between her and the child's biological father? What legal meaning should we derive from this act of complex individual and social meaning? We, as a community, cannot evade these difficult questions by foisting the answer off on the birth mother's choice. We must determine the implications of her changing choice and accept responsibility for the consequences imposed on her by the law. 


\section{B. Implications for Contracts: Spousal Guarantees}

The dilemmas presented by surrogacy contracts are more easily understood if we return now to the case of spousal guarantees. Recall that in the mortgage cases, the English courts struggled to reconcile their appreciation for the pressures of intramarital decisionmaking with the needs of banks for assurance in extending credit on faith of the signatures of both spouses. As the House of Lords has conceptualized the problem, the issue is whether a wife's "true wishes [have been] overborne because of her fear of destroying or damaging the wider relationship between her and her husband if she opposes his wishes." W1 We can now see this as an economic conceptualization of rational choice. The wife is released from the contract because it is not an implementation of her "true wishes," or her true assessment of the risks and benefits of the mortgage. Her assessment has been muddied by the fear of what refusing to sign will mean for her marriage. In the conventional framework, she is released from the contract because her choice is not rational; it fails to carry the moral and legal imperative of performance because it does not accord with the shop-window image of choices about future states.

The expressive theory of rational choice puts the conventional logic in this case in sharp focus. It would seem that the court is recognizing the reality of expressive choice, that a wife who signs a mortgage guarantee for the benefit of her husband may be expressing subservience, supportiveness, respect, love, or fear. Her frame for assessing her choice is oriented toward the present significance of that act and not the future calculus of financial risk. The problem for the conventional logic, however, is that having recognized this truth about the nature of choice in such a situation, it loses the rationale for enforcing the choice. Implicitly recognizing that the wife was not choosing to obtain a tradeoff of credit for risk, the court cannot see itself as acting merely to give the wife what she wanted. When the only relevant question is the factual one-is this what she chose?-the only possible answers are yes and no. In this case, the court cannot convince itself the answer is yes, and so, the contract is unenforceable.

The conventional logic must find the choice in these cases to be exceptional. If the notion that a promise is not directed instrumentally at achieving future consequences, but rather is oriented toward an expression of current relationships, is allowed to become a wide-

${ }^{61}$ Barclays Bank v. O’Brien [1993] 4 All E.R. 417, 424 (H.L.). 
spread interpretation of choice, then the unenforceability of contracts becomes the rule rather than the exception. And yet, it is not difficult to see that the same factors at work in the wife's case are at work in many other contracts. Indeed, the sharpest contrast is with the courts' treatment, or rather nontreatment, of the choices made by the husbands in these cases. It is certainly conceivable that husbands facing the bankruptcy of "their" businesses (which presumably produce income on which the family depends) are acting not on the basis of their "true" assessment of the financial risks and rewards, but rather on the basis of pride, fear, their conception of masculinity, fidelity to employees, self-loathing, and so on. A husband, like a wife, may not be acting on his "true wishes" but rather out of fear of the impact that not signing will have on his marriage, his self-image, or his wife's, parents', and children's image of him.

Anderson's theory normalizes such choice. Anderson does not see choices that are oriented to the expressive component of choice-what a choice means for self and others-as out of the ordinary. By seeing choice as routinely expressive, we are not at the end of contract reasoning-we are at the beginning. What reasons could there be for enforcing a promise when it is expressive and not instrumental?

It is not my goal to defend particular reasons that could be given for enforcement, but rather to emphasize that reasons are necessary to justify enforcement, and so I consider possible reasons here as examples. In the spousal guarantee case, possible reasons for enforcement appear readily. Presuming we are not truly in a category of coercion-which, doctrinally, undue influence is not-the first reason is the bank's reliance interest. On the faith of the wife's signature, the bank has handed over money. Whatever this signature may have meant for the wife-an expression of love or self-loathing-and whatever her reasons for now wanting to undo that signature-perhaps she realizes she was wrong to see the initial decision as she did or to have failed to demonstrate greater strength in her relationship with her husband-as between her and the bank, it would seem equitable that she bear the costs of her choice and of changing her mind. Those costs are the reliance costs, which in this case equal the value of the debt. If there is a reason not to apportion the reliance costs to her, it too is equitable: If the bank had reason to believe that she had little understanding of the financial risk, then its reliance was not reasonable. Hence, we obtain directly the logic of leaving the reliance costs with the wife when the bank has taken the further step of 
either explaining these details or requiring that the wife receive independent legal counsel.

The issue, then, from the starting point that ordinary choices are often expressive and not instrumental, is not whether a choice was made, but rather, who should bear the reliance costs when a new choice revises a choice made earlier. Seen from this vantage point, we can avoid the flawed logic of the spousal guarantee cases as they currently stand, which remedies the failure of a wife to act on her true wishes-the lack of adequately rational and hence enforceable choice-with independent legal advice. As already noted, independent legal advice does not speak to the risk the court articulates, namely that a wife will not act on her true wishes out of fear that opposing her husband's wishes will harm her relationship with him. Legal advice, however, does speak to the equities of the apportionment of the reliance costs of ordinary complex decisionmaking, and its ordinary revision over time, between the wife and the bank. When the issue concerns who should bear the reliance costs, the assessment of reasonable reliance comes to the fore. Indeed, a full range of considerations relevant to the relationship between the parties becomes pertinent. These include the commercial arm's length nature of the relationship between individuals and banks, the balance of power between the parties, the risk of advantage-taking, and the need to protect those with limited sophistication in financial matters.

These considerations, however, need not be applied on a case-bycase basis. Conventional contract logic has been shaped by a desire to preserve the core of contract and so to cabin relief from contract to exceptional cases on the margins. When the reliance interest is the rationale for enforcing a contract, it can be the case that a given category of contracts is assessed together. Therefore, the spousal guarantee cases can all largely rise or fall together, based on an assessment of how reliance costs should be distributed. As Fuller and Perdue have argued, contracts are routinely enforced because of the reliance interest that contracts generate. ${ }^{62}$ There is no suggestion in this claim that this need be a case-by-case inquiry, as an equitable doctrine or section 90 of the Second Restatement of Contracts requires. As a matter of doctrine, it is possible to decide that any contract is enforceable because of the reliance interest it generates, or that some

${ }^{62}$ See L.L. Fuller \& William R. Perdue, Jr., The Reliance Interest in Contract Damages: 1, 46 YALE L.J. 52 (1936) (discussing the motives that may lead a court to grant legal sanctions against one who has broken a promise); L.L. Fuller \& William R. Perdue, Jr., The Reliance Interest in Contract Damages: 2, 46 YALE L.J. 373 (1937) (same). 
are not enforceable because reliance on a contract of a given type is not reasonable.

Reliance may thus be one reason for enforcing a contract, such as a spousal guarantee contract, that looks beyond the mere fact of choice. A second reason is institutional policy: The institution of mortgage guarantees depends on the ordinary enforceability of the guarantee. Without ordinary enforceability, the family home becomes "sterile," in the words of the House of Lords, as a source of collateral to secure credit for family endeavors. Thus, whatever the meaning of the guarantee for a given individual (wife or husband), the guarantee is enforceable because of the threat that nonenforcement poses to the stability of this valuable institution.

Whether this is a good reason for enforcing guarantees depends on our assessment of the value of the institution and the nature of the risk that failure to enforce the contract will pose to the institution for others. Moreover, this instrumental assessment of the value to society of the institution reflects a Rawlsian, agent-centered reason for enforcement and suggests a wide variety of factors that may be relevant. Recall that Rawls argued that the reason an individual is morally bound to perform a promise is because the principle of fairness requires that one who invokes a convention must adhere to the rules of the convention. ${ }^{63}$ The convention of mortgage guarantees, to be valuable, requires that they be enforceable. Hence, one who benefits from the institution of mortgage guarantees ordinarily, in fairness, is bound by the conventional terms. The inquiry into fairness, however, also could include inquiry into the fairness of the terms of the convention. Again, the balance of power and sophistication between the parties might be relevant, as might be the presence or absence of independent legal advice.

To examine the nature of this contract logic and the way it grows out of a reconceptualization of Anderson's theory of rational choice, compare the spousal guarantee cases with commercial financing contracts. In the standard commercial setting, the ordinary frame in which a financing contract is assessed is the classical instrumental assessment of future consequences. Pride, loyalty, and defiance of the odds all intrude on the commercial actor's calculus of risks and rewards. But, within the frame of commercial decisionmaking, they would be understood to be intrusive. Particularly where there are multiple decisionmakers-partners, advisers, or directors-the deci-

6s See RAWLS, supra note 50, at 344-48. 
sion to enter into a financing contract will be made in a framework in which the common ground is risk allocation. That is what the decision to contract will mean for the decisionmakers. And in such a case the reason the contract is enforced is because that is what the decisionmakers chose: to assume a future risk.

This line of analysis echoes Thomas Scanlon's emphasis on the importance of the meaning of a promise to the actors involved. Scanlon argues that promises may be enforceable, even in the absence of a convention of enforcement, because the self-conscious understanding of the promisor gives rise to moral obligation. For Scanlon, this is the case where a promisor knows that the promisee is seeking assurance and gives the promise for that reason. In Scanlon's formulation,

If (1) A voluntarily and intentionally leads $B$ to expect that $A$ will do $x$ (unless B consents to A's not doing $x$ ); (2) A knows that B wants to be assured of this; (3) A acts with the aim of providing this assurance, and has good reason to believe that he or she has done so; (4) B knows that $A$ has the beliefs and intentions just described; (5) $A$ intends for $B$ to know this, and knows that B does know it; and (6) B knows that A has this knowledge and intent; then, in the absence of some special justification, A must do $x$ unless $B$ consents to $x$ 's not being done. ${ }^{64}$

Seen through the lens of Anderson's theory, Scanlon's rather extensive list of conditions describes a particular frame in which a promise is made. Indeed, it includes not only the frame for the promisor but also for the promisee.

Scanlon describes the shared frame for the vast majority of commercial financing decisions. But this frame does not describe most spousal guarantee decisions. And so, although "because this is what you chose" may be sufficient reason to enforce a commercial financing contract, more is needed to justify the enforcement of the spousal guarantee, such as the protection of reliance interests or the protection of a valuable convention.

\section{Implications for Contracts: Separation Agreements}

If we now turn to the dilemma posed in the conventional logic by separation agreements, we will see a further point: Once a contract logic admits that enforcement of promises-other than those selfconsciously made in a frame structured by risk allocation-requires reasons beyond "she chose," then it also admits of greater distinction

${ }^{64}$ Thomas Scanlon, Promises and Practices, 19 PHIL. \& PUB. AFF. 199, 208 (1990). 
among categories of contracts. Just as the apportionment of reliance costs might vary from setting to setting, so too might the value of the convention of contracting and the risk that nonenforcement poses to the convention.

Recall that, under conventional logic, the problem with separation agreements is ambivalence about according to a contract signed at the time of separation the power to determine the financial relationship of former spouses at some point in the future. This is a power that is not available, by contrast, to court orders determining support; the issue in the Canadian cases has been whether the separation agreements can oust the statutory jurisdiction of the courts to modify support payment where there has been a material change in circumstances. The claim that they can oust state jurisdiction rests on the assertion that respect for the autonomy of separating wives who voluntarily sign such agreements requires the courts to enforce the agreement except in extreme circumstances causally attributed to economic dependency in the marriage: this is what she chose.

The economic conception of choice causes us to see the decision to sign a separation agreement as the product of a weighing of the costs and benefits of the available alternatives, hence justifying the idea that enforcement is merely deference to the parties' original wishes. Anderson's conception, however, allows us to see in the decision to sign an agreement potentially many things beyond this consequential assessment: the playing out of marital roles, lingering identity with an ex-spouse, an expression of maternal responsibility for the reduction of conflict or legal expenses, an assertion of control and self-respect, guilt, or punishment of self or others. Later, through growth and reflection, the values expressed in the decision to sign the agreement may no longer appear rational to the signer. What, then, is the legal significance of the earlier choice? What reasons are there for according to the earlier choice the power to now determine the relationship between former spouses? Again, I will suggest some possibilities without intending to resolve the issue on the merits.

Consider first the reliance interest. As with the spousal guarantee cases, it would seem a natural starting point to say that, whatever meaning the decision to sign a separation agreement may have had for the wife at the time of signing, if the husband has relied on that signature she and not he should bear the cost of that reliance. But at least two distinctions from the spousal guarantee cases arise. 
First, it is not clear that former husbands typically have a reliance interest in the original separation agreement. They have an expectation interest-an expectation that they will be called on to pay so much for so long-but it is difficult to see reliance. Specifically, how is there a change of position that takes place as a consequence of the separation agreement? Certainly, the husband's earning, spending, and investment decisions will be made with reference to a given support scheme. Provided, however, that support modifications are prospective, not retroactive, and are based on the financial position of the former spouses at the time modification is made, none of these decisions are made in reliance on the support scheme of the separation agreement. Nor will the decisions create losses for the husband as a consequence of the modification. The modification, of course, will create losses; but those losses are not attributable to reliance on the separation agreement.

If, by hypothesis, the modification replaces the separation agreement with the support scheme that would have been available as a modification of court-ordered support, his position is not worsened by virtue of his having entered the agreement. This is true, a fortiori, if the separation agreement itself put in place the equivalent of what a court would have ordered as fair support at the time of separation. And to the extent the husband's position worsened-if, for example, he made lump-sum payments up front that exceeded the present value of fair support over the period between the agreement and the modification-then modification can take that into account to avoid imposing any reliance losses on him.

Even if reliance losses could be identified in the case of the separation agreement, however, there is a second reason why protecting the reliance interest may not provide as forceful a reason for enforcing the separation agreement as the spousal guarantee. Former spouses have a financial responsibility to each other; this is the essence of the spousal support aspect of family law. The starting point for the allocation of reliance costs, then, is different in the case of separation agreements; it is a starting point of disentangling economic interdependence and the extensive reliance that develops in the course of marriage.

Consider now the other possible reason for enforcing spousal guarantees: the protection of a valuable contract convention. I will begin by focusing narrowly on the convention of separation agreements and then look more broadly at the convention of contracting generally. 
We must be able to identify the value of separation agreements to society generally to invoke instrumental justification for enforcement. The value of finality and an end to litigation and conflict is an obvious starting point. ${ }^{65}$ The background regime of family law, however, is already structured to achieve these goals; modifications of courtordered support payments will be made only if a change in circumstances causes an inadequacy in the original order that outweighs the interest in finality. Thus, one source of finality arising from the separation agreement-the substantial reduction in the probability of modification under contract relative to the probability under the background regime-goes beyond what family law deems to be the proper balance between fair support obligations and finality. This cannot therefore be a direct source of social value itself. But it could be a value for the contracting parties, particularly the payor, that changes the content and probability of separation agreements. This then raises the question of whether such changes are desirable for society.

A significant reason why these changes are socially desirable is that separation agreements economize on the costs of dispute resolution, avoiding public and private litigation expenses. The inability to waive the right to seek modifications from the court is a loss if separation agreements are reached less often. The effect here-and it may not be significant since court-ordered support, which is at least as likely to be modified as the separation agreement, is the only alternative ${ }^{66}$-must then be weighed against the same considerations that justify the cost of modifying family-law proceedings to obtain greater fairness in support agreements.

But what about the idiosyncratic value of finality to the parties themselves? Is a convention of contracting out of modification rights valuable because it allows parties to achieve a private balance of finality and future fairness? This perspective recalls risk allocation

${ }^{65}$ See Stephen M. Grant, The End of Finality, 27 R.F.L.4th (Can.) 252, 252 (1997) (noting that court interference with agreements "misguidedly subordinates the understandable desire of divorcing spouses to achieve, if possible, finality by consensual agreement").

${ }_{65}$ As a point of reference, it is generally not possible to waive the right to modify child support or child custody arrangements, and yet agreements on these matters are routinely reached. Indeed, some courts have concluded that agreements on custody can be modified without a showing of change of circumstances-the standard for modification of court-ordered custody-because the agreement does not reflect judicial inquiry into the facts relevant to custody. See Joan G. Wexler, Rethinking the Modification of Child Custody Decrees, 94 YALE L.J. 757, 760 (1985). 
through contracting. Trades in risk can be valuable; the markets for insurance, warranties, and financial guarantees are valuable institutions for this reason. Divorcing spouses may seek to trade risk by compensating the wife, for example, for assuming the risk of future changes in circumstances. But as with the distinction between commercial-financing agreements and spousal guarantees, the difficulty with separation agreements is that we cannot feel confident that the risk-allocation frame is the frame in which the contract was made.

In Santosuosso, at the end of a long-term, traditional marriage, the wife agreed to a separation agreement providing her with $\$ 1400$ per month for twenty-four months, stipulating that " $[t]$ hereafter, regardless of her situation, the wife [would] forever be responsible for her own support, regardless of any change in circumstances, no matter how catastrophic such change in circumstances might be and release[d] any and all claims which she might have for any further support in the future. ${ }^{67}$ Two years after leaving the marriage, Mrs. Santosuosso was still not economically self-sufficient, likely because she only possessed a ninth-grade education, a secretarial certificate, and the hope of completing a college diploma to enable her to obtain good employment.

The Santosuossos' separation agreement purports to establish, according to conventional logic, that the agreement is a deliberate trade in risk. But if we understand the possible stories in Santosuosso-a story of a woman hoping to prove her worth in the face of her husband's remarriage to a woman with postgraduate degrees, or a story of a woman with a sense of hopelessness and self-reproach at the end of her marriage, engaged in conflict with her children-it is not difficult to imagine that the frame of that decision for her was not a matter of trading risk. The meaning of the agreement as an end in itself, and what it said about her, may have dominated her decision to sign. Even words as strong as those found in the Santosuossos' agreement cannot dispel the likelihood that a wife has agreed to them, not to allocate risk, but to make a statement about how she values herself, her family, and her situation. The policy value of facilitating idiosyncratic allocations of risk is a complex matter of distinguishing those cases in which the value is indeed at stake and those in which it is a false interpretation of the values of the parties.

There are some clues and further policy considerations that could offer guidance to courts. Courts could examine the content of the

${ }^{67}$ Santosuosso v. Santosuosso, 32 O.R.3d 143, 145 (Gen. Div. 1997). 
trade in risk to determine whether there was in fact a benefit conferred on the wife who agreed to forgo her rights to modification. With the limited information set out in the opinion, it is perhaps difficult to find this in Mrs. Santosuosso's case. From the court's perspective, Mrs. Santosuosso gave up substantial, long-term rights to economic support. (Recall that in the Moge case, the Supreme Court of Canada held that in a traditional marriage, support obligations could extend more than sixteen years after the end of the marriage.) If a court is to enforce a separation agreement in order to achieve the policy goal of facilitating transactions in risk, it would seem that more evidence of a real trade in risk is necessary before we can be confident that risk allocation was the frame of the decision to contract.

There is, however, another consideration. In Mrs. Santosuosso's case, the spousal support agreement was part of "what was happening with the house proceeds, what was happening with the debts, what was happening with the children, what was happening with the child support." Als Although we would want to look at the package in order to determine whether it was plausible to assert that Mrs. Santosuosso entered into the agreement in a risk-allocation frame, the nature of the package itself raises questions. First, it increases the likelihood that the decision to waive modification rights was made in a frame that focused on issues other than achieving value through redistributing risk, such as responsibility or guilt towards her children. Second, it is not clear that transactions that involve trading the risk of future financial distress for increased access to children or child support or the ability to stay in one's home or to face an uncertain future with reduced $\mathrm{debt}^{69}$ are trades that, from a social point of view, we want to facilitate. Remember that the policy justification we are examining looks to the social value of protecting the convention of contracting out of modification rights. In light of the fact that women and children suffer greater economic losses from divorce than men, ${ }^{70}$ it is not clear that the law should enforce separation agreements in order to facilitate trades that result in even less protection than family law's background regime offers. The social value of facilitating such trades must be assessed against this background. However one comes out

cs Id. at 155 (quoting counsel for Mr. Santosuosso).

${ }^{69}$ We do not have the details of the package and so I am speculating about what the tradeoffs might have been in the package.

${ }^{70}$ See LeNORE J. WeITZMAN, THE DIVORCE REVOLUTION 337-43 (1985); Robert S. Weiss, The Impact of Marital Dissolution on Income and Consumption in Single-Parent Households, 46 J. MARRIAGE \& FAM. 115 (1984). 
on the policy question, the point remains that the enforceability of separation agreements is a matter of assessing, in a category-specific way, the instrumental value of a convention of contracting out of modification rights in a separation agreement.

Suppose we concluded that this convention, which I suggested was a narrowly defined convention, was not instrumentally valuable. The possibility remains that the institution of contracting as a whole, which clearly does have value in a multitude of settings, will be at risk if separation agreements are unenforced. This raises the issue of the separability of categories of contract. The convention of contracting in the marital dissolution setting is sufficiently distinct from other settings, such as commercial contracts, that the likelihood of disrupting these other contracts is extremely small. I raise this consideration because it is both important to include it in the assessment of the value of a particular convention of contracting and to recognize the different social meanings that "contract" has in settings that we reliably can demarcate.

Thus, the policy justification can be seen to vary across categories of contracts. Once we move beyond the mere fact of choice as the determinant of enforceability-as Anderson's conception of rational choice-we open up distinctions among contracts. The reasons to enforce spousal guarantees may not extend to the case of separation agreements.

\section{Implications for Contracts: Surrogacy Concluded}

With the analysis of the comparatively easy cases of spousal guarantees and separation agreements in hand, we now can return to surrogacy contracts. While the ultimate issues in surrogacy remain deeply troubling, the analysis thus far sets out a way of sorting through them.

First, we can confidently reject the notion that surrogacy agreements are framed by the parties as a deliberate transaction in risk. Birth and intending parents do not reach an agreement to arrange for the conception and gestation of a child and the surrender of parental status in order to reap the value of transferring risks. Birth mothers do not enter into the arrangement in order to gain compensation in exchange for their willingness to assume the risk that surrender of their parental interests will cause them great pain. Intending parents do not pay in order to get birth mothers to take on this risk. Birth mothers do not promise, like insurers, to relieve in- 
tending parents of the risk that they will remain childless. Intending parents do not pay the equivalent of an insurance premium to gain peace of mind and a reduction in uncertainty. Risks such as these arise and are indeed allocated as a consequence of the legal treatment of the agreement, but they are not the object of the contract for the parties. Thus, there is no force to the claim that the surrogacy contract is enforceable merely because the birth mother chooses, like an insurer or guarantor, to assume the risk of the harm she now seeks to avoid.

Does another potential reason to enforce the agreement arise from the fact that the birth mother originally promised to relinquish her parental status? Posner argues that it does by claiming that failure to enforce the birth mother's promise licenses her to extort a higher payment from the intending parents. ${ }^{71}$ This is an application of the concept of opportunism: reneging on a contract in order to take advantage of the changed position-the reliance investmentsof a contracting partner and demand better contractual terms. From an instrumental point of view, opportunism is costly because parties may expend resources protecting themselves from opportunism, reduce their valuable reliance investments in order to minimize their exposure, or fail to reach agreements in the first place. From an ethical perspective, opportunism is unfair advantage-taking. On the faith of a promise and to the benefit of the promisor, the promisee has made herself vulnerable to the promisor; it is wrong for the promisor to then take advantage of that vulnerability and renege on the promise. Here we can see that the fact of the promise could itself give rise to an obligation not to renege opportunistically, grounded either in the instrumental value of a rule against opportunism or the ethics of the situation.

In the surrogacy setting, the question whether the birth mother's refusal to relinquish custody of the child born of the arrangement is opportunistic raises two concerns. The first is straightforward. It seems implausible that opportunism motivates those (apparently few) birth mothers who choose not to relinquish custody. Moreover, this concern easily could be addressed without routine contract enforcement; courts instead could refuse to enforce, or require restitution of, increased payments made on the basis of an explicit or implied threat to retain custody. Brokers could establish escrow accounts to preserve the birth mother's ability to make restitution of any wrongfully ex-

7 See POSNER, supra note 59, at 422. 
torted gains. Assuming a surrogacy market exists, it is simply not difficult to imagine market solutions to this problem.

The less straightforward concern with the opportunism justification for enforcement is the premise that the intending parents have become locked-in to the surrogacy agreement and so become vulnerable to an opportunistic extraction of what economists have called quasi-rents-the surplus associated with continuing with a given relationship over the alternative of discontinuing the relationship and moving to the next best option. This surplus is positive when the contracting parties have sunk costs in the relationship that must be abandoned if the relationship is severed. This puts the parties at a negotiating disadvantage once a relationship has begun that they were not under before an agreement was struck. ${ }^{72}$ The reason the analysis of opportunism is difficult in the surrogacy case, if it is even a factor, is that it is not clear that the intending parents have made investments that can be exploited in this way-that they have a reliance interest at stake. Analyzing opportunism as a reason to enforce a surrogacy contract merely because the choice was made to enter into the contract, therefore, requires that we analyze what we have already identified as a key reason for enforcing contracts, namely, the existence of a reliance interest in the contract.

What is the nature of reliance in the surrogacy setting? How is the position of the intending parents altered as a consequence of the agreement? Clearly, any expenditures they have made on behalf of the birth mother constitute reliance, and will probably be recoverable as restitution in the event the birth mother retains custody. But to focus on this trivializes a difficult and contested aspect of surrogacy. In cases in which the intending father is the genetic father, is his transfer of genetic material to the birth mother reliance? What about the forgoing of other opportunities to enter into surrogacy agreements or adoptions? More difficult still, what about the intending parents' emotional investment in the expectation that a child will soon arrive in their home? Even if the latter is properly characterized as an expectation interest-which, unlike reliance, does not generate an ethical obligation in the absence of a convention that makes protection of expectations the obligation of the promisor ${ }^{73}$-there does

${ }^{72}$ See Benjamin Klein et al., Vertical Integration, Appropriable Rents, and the Competitive Contracting Process, 21 J.L. \& ECON. 297, 298 (1978).

${ }^{73}$ Generating expectations in others, unlike generating reliance in others, does not carry obligation on its own; the obligation comes from the convention of contract. What we are exploring, of course, is what that convention should look like. We can 
seem to be merit in the idea that as the date of delivery approaches, the intending parents become increasingly emotionally attached and hence vulnerable to demands for payments beyond what they would have agreed to at the outset. This is the essence of opportunism.

There are no easy answers to these questions; they go to the heart of our debates about the meaning of surrogacy arrangements and their value. Is genetic material properly considered property in which the intending father has a legally cognizable interest? ${ }^{74}$ Does this way of characterizing the father's interest in his contribution to the conception of the child ignore the true nature of his reliance, which is his decision to father a child only if he is assured he will raise that child? If the intending parents have forgone other opportunities for surrogacy or adoption, are these opportunities merely delayed by nine months? Or might they be permanently forgone because the intending parents cannot bear to go through the process yet again? Who bears the burden of protecting themselves against emotional pain by resisting the pull to become emotionally invested in the child during the pregnancy: the intending parents or the birth mother?

These issues raise serious questions about the reliance interest as a justification for enforcement of surrogacy agreements. Realistically, none of these deeper reliance interests can be adequately compensated with money, even assuming that birth mothers have the resources to provide compensation or that insurers could step into the breach. More fundamentally, the nature of reliance in this setting raises such deeply troubling issues, issues that go to the core of our contested social attitudes towards surrogacy, that it is far from straightforward for contract law to enforce these agreements on the basis of reliance. It is one thing to enforce a contract on the basis of what is universally agreed to be reliance, but it is something else entirely for contract law to protect a reliance interest whose existence is deeply contested.

It is almost impossible to analyze surrogacy as a matter of contract law without addressing the fundamental questions surrogacy raises as a matter of ethics and policy. In the absence of a contract, the birth and genetic parents of a child have-legal relationships established by family law, parentage statutes, and adoption statutes. As in the case of

easily conceive of a convention in which contract protects only the reliance interest and expectations remain, as in the noncontractual case, the responsibility of the one who expects.

${ }^{74}$ See Jennifer Nedelsky, Property in Potential Life?: A Relational Approach to Choosing Legal Categories, 6 CAN. J.L. \& JURIS. 343 (1993). 
separation agreements, these background relationships provide a starting point for the assessment of the obligations arising from the reliance of a contract. The parents of a child have background obligations to each other and to the child, and the just allocation of reliance obligations between them must take into account those background obligations. Every case in which parental rights are contested, whether there is a marital relationship or not, involves the loss of reliance, the disruption of expectations, and the emotional pain of changed or severed relationships. Family law, in the absence of contract, allocates those losses-and the fairness of their allocation in the presence of a contract has to be assessed against that context. If it is just to impose reliance losses, or to disrupt deeply held expectations of relationship in order to protect a child's best interest in the absence of a contract, it also may be just to do so in the presence of a contract.

The alternative that contract seems to offer for an easier resolution of this difficult issue on the basis of "choice" is a dangerous mirage. The decision to enter into a surrogacy contract is an act that has complex meaning for the parties involved. Decisionmaking is not always, or even routinely, instrumental. Thus, contract enforcement is not justified merely because "she chose." Following the path of justification for enforcement brings us to the essence of the complex and contested ethics of surrogacy. The lesson is that, even as a matter of contract law, the legal significance of surrogacy contracts is a matter of ethical and social policy. Contract here accomplishes little in taking the relationships among the parties involved beyond the background of family law.

Having entered the contract, the birth mother is not bound, by virtue of that act alone, to perform. If she is required by contract law to perform, a contract law built on Anderson's understanding of rational choice as expressive choice, it will be because courts or legislatures determine that she, rather than the intending parents, should bear the pain of the loss of the child, or that the best interests of the child require this, or that this mechanism of producing children for childless couples is of social value and so must be protected. These same considerations may well lead us to the conclusion that she is not contractually bound; not because contract must be limited in this sphere or because the birth mother is not competent to contract in this sphere, but because contractual logic itself leads us to that conclusion. 


\section{E. Transcending the Feminist Dilemma of Choice}

And so the dilemma of choice is transcended. The autonomy of the chooser is not pitted against her well-being. Refusal to enforce a surrogacy agreement, a separation agreement, or a spousal guarantee is not a denial of respect for the autonomy of a woman who chose to enter into the agreement. It is an acknowledgment of what autonomous, rational choice means. It is acceptance that the consequences of choosing to enter into a contract do not follow from the fact of the choice alone, but rather from the consequences the law attaches. The question of what consequences attach requires an inquiry into factors outside the fact of choice: the reliance interest of the other parties to the contract or the policy interests of society at large in protecting a legal convention.

Anderson's theory of expressive choice allows us to transcend the feminist dilemma of choice in contract because it emphasizes the incommensurability of value and choice, and insists that we pay attention to the fact that choices are evaluated in different ways, according to different frames. Moreover, it rejects the conflation of all choices into the instrumental, consequential, risk-allocation frame that the economist's model employs. The feminist dilemmas that come to the fore are troubling precisely because these are settings in which the instrumental risk-allocation frame is patently inappropriate. In Anderson's view, it would be irrational to evaluate the state of affairs in purely instrumental or consequential terms. These are settings in which it would represent a failure to adequately express values-of love, self-worth, respect, duty, and so on-to choose as the economist understands us to choose.

A contract logic based on Anderson's theory of expressive choice might require enforcement of contracts for mortgage guarantees or support payments or parental status. But enforcement will not be due to indifference to the reality of evolving rational choice, or because a woman's choice has nullified the background claims that she has to relief from loss of her home, to support payments, or to a relationship with a child to whom she has given birth. Rather, enforcement will be required because the full picture of those background claims, including the reliance interests generated by her choice and the policy interests others have in the protection of a convention of contractual choice, justifies enforcement. If enforcement is not justified, it will not be a failure of respect for the autonomy of the woman who made the promise. It will not be because she is not capable of rational choice or in need of exceptional protection from the courts. It will, 
indeed, be because she chooses rationally, both at the time of her contract and at the time she changes her mind, and because contract law understands what this means.

\section{SUMMARY AND CONCLUSION: BEYOND THE FEMINIST PUZZLES}

Anderson's reconceptualization of rational choice gives us a basis for rejecting the conventional logic of contract law that enforces a contractual choice simply because it is a choice. When the choice is expressive and not instrumental, as it often is, we cannot evade the need to provide justification for the decision to attach legal consequences to the choice.

In working through the feminist puzzles discussed above, I have argued that the structure of a contract law based on an appreciation of expressive choice would begin with an assessment of whether a given category of contract normally is entered into in a risk-allocation frame. Absent the risk-allocation frame, there is a need to assess the reasons there might be for enforcement. I have suggested two relevant inquiries for the identification of potential reasons for enforcement: (1) whether there are reliance interests at stake and what the appropriate allocation is of those reliance interests against the background relationship between the contracting parties; and (2) whether there are instrumental justifications for enforcement flowing from the value of contracting in a given case and the risk that nonenforcement within that category poses to the stability of contracts in other categories. Note that, other than the initial inquiry into whether a riskallocation frame can be fairly presumed, Anderson's contract logic does not proceed by judging the quality of the choice or the adequacy of the frame in which it was made. To do so would follow the conventional logic, which holds that all that matters is whether a choice was adequately rational. Perhaps paradoxically, once we have recognized that choices are routinely expressive and complex in their meaning, we break free from the need to assess the quality of choice. The normative power of the choice comes not from how good it is, but from factors outside of it: reliance, institutional value, and so on. We will still care about the voluntariness of the choice and the information available to the person who made it. What makes this contract and not tort is still that it is the voluntary and informed choice of the promisor to enter into a contract that triggers potential liability. Having established those factors, however, we shift attention outside of the promisor to the reasons found in relations with other parties for enforcing the promise. 
I have explored the implications of Anderson's expressive theory of choice in terms of feminist puzzles because those dilemmas of choice expose the inadequacy of a contract law founded only on the conventional view of rational choice. The analysis, however, extends across the domain of contract law.

First, this analysis preserves the core of traditional commercial contract, including contracts for insurance, warranties, futures contracts, financing agreements, profit-sharing agreements, and the traditional remedy of expectation damages. We can feel confident that these traditional commercial contracts are evaluated within a riskallocation frame. Moreover, transactions in risk are of commercial value, permitting parties to shift risk to those able to bear it at lower cost or better able to create incentives for effort and care. Enforcing contracts made within a risk-allocation frame is instrumentally valuable because such transactions would be largely impossible without enforcement.

Second, my analysis preserves a core reason for enforcing commercial contracts up to expectation-protection against opportunism. Although I have rejected fear of opportunism in the surrogacy setting, strategic and opportunistic behavior clearly is a factor in commercial relationships. For example, price or quality agreements are less valuable if they require renegotiation to avoid exposing either party to a credible threat.

Not all contracts, however, are breached for opportunistic reasons-nor are all ex post renegotiations of price or other terms opportunistic. Contract breach and modification are often about adjusting to evolving conditions and information. This need for adjustment, and the fact that not all contracts are formed in a riskallocation frame, underlies the distinction between discrete and relational contracts. Discrete contracts are really the paradigm of conventional contract law. From the analysis developed here, it is clear that discrete contracts represent the subset of contracts formed in a risk-allocation frame and/or contracts in which the parties should be held to their agreements in order to prevent opportunistic defection. Discrete contracts are typically sales or commodities contracts, transferring property interests and commercial risks. Relational contracts, in contrast, structure cooperative activity that extends over time. They encourage reliance by coordinating efforts, communicating goals, and securing commitments. They provide mechanisms for resolving disputes and adapting to uncertainties. They establish governance schemes and spheres of discretion. They are woven from 
and into a fabric of societal and relationship-specific norms. They may make only a limited contribution to the parties' understanding of their obligations to one another.

Analyzed from the perspective of a contract law based on the expressive theory of choice, relational contracts comprise a large category of non-risk-allocation contracts. ${ }^{75}$ Indeed, the expressive theory of choice explains the values and norms emphasized by relational contract scholars-values such as solidarity, trust, reciprocity, and cooperativeness. My analysis suggests that the approach to enforcement of such a contract must go beyond the fact of consent to the contract. We need to consider the reliance interests at stake, and allocate responsibility for those interests based on the relationship between the parties. This will lead to a reliance remedy for breach of relational contracts: a remedy that secures cooperation but distributes the losses associated with a relationship that has become less tenable or less valuable than either of the parties had expected. The need to look beyond the fact of choice in enforcing relational contracts supports giving attention to the norms emphasized by many relational contract scholars. Going beyond the fact of choice also avoids the "death of contract" result: Because choice alone is not a sufficient ground for contractual enforcement, enforcement grounded in external aspects of the choice, such as the relationship of the parties and the just distribution of reliance costs between them, is integral to the idea of contractual obligation.

Enforcement of relational contracts on the basis of an expressive theory of choice implicates instrumental concerns. Potential opportunistic breach would justify enforcement up to expectation. Minimizing the transaction costs of alternative governance structures would require making salient distinctions among contract categories. For example, franchising contracts, employment contracts, and government contracts might warrant differential treatment, while finer distinctions among commercial contracts might not. Indeed, much of the economic analysis of relational contract law is of this instrumental variety. The expressive theory brings agent-centered contract logic that supports this approach.

The expressive theory of choice also directs attention to the distinctions among contract categories. Conventional contract law, like conventional rational choice theory, treats all decisions to contract as

${ }^{75}$ Relational contracts can contain risk-allocation terms. My focus here, however, is on what distinguishes relational from discrete contracting. 
essentially the same. Consequently, it advances uniform reasons for enforceability across all categories: commercial, family, employment, government; relational and discrete. This conflation of contract categories explains much of the tension in modern contract law. Without the expressive theory of choice, accounting for the reality that presses through the gaps in contract law poses the same dilemma as the feminist puzzles do; under conventional logic, looking beyond the existence of voluntary choice amounts to paternalism and interference with choice. Conventional logic is based on a flawed conception of choice. Adopting Anderson's theory of choice, we can transcend the dilemma in either feminist settings or commercial contract settings. Respect for the multiplicity of frames in which a decision to contract can be made often entails looking beyond the fact of choice to the complexity of what it means to choose. 
